\title{
Corruption and its Influence on Economy with Focus on Inflow of Foreign Direct Investment
}

\author{
Petr Procázka ${ }^{1}$, Mansoor Maitah ${ }^{1} \&$ Ales Pachmann ${ }^{2}$ \\ ${ }^{1}$ Department of Economics, Faculty of Economics and Management, Czech University of Life Sciences, Czech \\ Republic \\ ${ }^{2}$ President of APA, Civic Association, Prague, Czech Republic \\ Correspondence: Mansoor Maitah, Faculty of Economics and Management, Czech University of Life Sciences \\ Prague, Kamýcká 129, 16521 Praha 6, Suchdol, Czech Republic. Tel: 420-234-382-139. E-mail: \\ maitah@pef.czu.cz
}

Received: May 27, 2015

Accepted: June 13, 2015

Online Published: October 31, 2015

doi:10.5539/mas.v9n12p213

URL: http://dx.doi.org/10.5539/mas.v9n12p213

\begin{abstract}
This paper evaluates the impact of corruption on economic sphere, with special emphasis on inward foreign direct investment (FDI), as investment is one of the main factors of economic performance. The impact of corruption on FDI inflows is studied globally. Based on the research of contemporary literature, it was found that the level of corruption has not clear negative impact on FDI, what is leading to the formulation of the research objectives of this work. The results confirm the 88 countries for the years 2000, 2005 and 2011, the existence of a negative relationship between the level of corruption and FDI inflows, this is a statistically significant relationship and it is this relationship further quantified within the regression model. In conclusion, it is proposed to include additional explanatory variables in addition to the degree of corruption to understanding the causes FDI inflows.
\end{abstract}

Keywords: corruption, foreign direct investment, economy, regression, correption perception index

\section{Introduction}

Corruption has a negative impact on the state of the public budget, causes economic decline in the state, disrupts political stability. Also causes an increase in crime and the shadow economy (Buehn \&Schneider, 2007). There is strong empirical support for the negative impact of corruption on the ratio of investment to GDP and GDP growth, productivity, government services and healthcare, the structure of government spending and tax revenues (Lambsdorff, 2004).

Corruption is generally perceived as a cost of doing business or income tax expense. We can therefore expect that corruption leads to reduced profitability and investment. Corruption in such a way can be considered as unpleasant obstacle for investors, which will play a role in their decision on the issue of FDI. Empirically minded literature on the topic, however, has mixed results. There are studies that support and negate the hypothesis of a negative relationship between corruption and FDI (Al-Sadigo, 2009). This issue is discussed in this paper.

\subsection{The Level of Corruption and Transparency International Index}

In 2000, Transparency International (TI) defines corruption in public administration as the abuse of public power or public resources for private gain.

For the purpose of this work expresses the level of corruption frequency and amount of financial amounts bribed public officials by business entities in individual countries.

TI publishes annually so called "Corruption Perception Index (CPI)" TI. Based on CPI individual countries sorted by level of perception of corruption among public officials and politicians.

Each country is judged on a scale from 0 to 10 , where 10 represents the lowest level of corruption and 0 the highest. It is a composite index. Individual surveys included in it are provided by independent and reputable institutions reflect the opinions of experts and business leaders. TI provides on its website information on the methodology and the CPI. 


\subsection{The Impact of Corruption}

This chapter discusses in detail the question of the impact of corruption on GDP, and particularly its impact on foreign direct investment.

In the forefront of experts in the field of economics was given the theme of corruption, particularly thanks to the article by S. Rose-Ackerman (1975), "The Economics of Corruption".

Empirical research in the field of corruption is relatively young. According to JG Lambsdorff (1999) can be concluded that corruption often goes hand in hand with a policy distortions of competition, income inequality and lack of competition. Corruption at the international level often occurs in cross-border activities and the various studies are reflected by the idea that some exporters and donors to be more inclined to favor countries perceived as corrupt and thus contribute to the high level of corruption.

\subsection{Corruption and Gross Domestic Product}

Economist P. Mauro (1995) examined the effects of corruption using corrupt index and GDP per capita. He showed that the decline in corruption index by one standard deviation significantly increased the annual GDP per capita growth to $0.8 \%$.Hobbs estimated that the World Bank contracts falls to around 10-15\% commission from its values and is lost due to corruption $5 \%$ of the investment and infrastructure maintenance costs (Kenny, 2006) Firms will then try such an investment to tackle corruption, either through higher prices for goods and services, or on the basis of lower quality, or both (i can bribe supervising inspectors who check the quality). It is likely that the companies then even to new customers will not try to reduce prices or improve quality. Investments in corrupt networks and know-how to becomes a competitive advantage for companies. It is logical to remain corrupt for such companies (GTZ, 2008)

One can observe a significant effect of corruption on GDP. The rise of corruption within the CPI by one point reduces productivity by $4 \%$ of GDP, an improvement of 6 points, GDP would increase by about $20 \%$ (Lambsdorff, 2014). Corrupt individuals usually hide money from corrupt activities into "safe havens". Approximately $\$ 100$ billion is the estimate for the global amount of such money. 70 million received back to Nigeria from criminal activity Abachiho and the Philippines over $\$ 600$ million from the reign of Marcos. Corrupt governments and political systems emit finance especially for military purposes and purchases and under-investing in education and health, and because of that corrupt gains from such an arrangement is easier to obtain.

\subsection{Corruption and Its Impact on Foreign Direct Investment}

International business managers up to one-third believe that corruption increase the cost of international project by more than $10 \%$ and one sixth of them believe that it is even more than a quarter (Bray, 2007). The survey among business executives, which were more than 390 questioned, nearly 45 percent said that they did not enter the market or did not use the business opportunity because of corruption risks (PricewaterhouseCoopers, 2008). Wei says that the increase in the level of corruption from Singapore to the level of Mexico has the same negative effect on foreign investment, as more than $50 \%$ increase in taxes (WEI, 2000). Highly corrupt environment significantly reduces the attractiveness and value of domestic firms in the eyes of investors, as shown by the analysis of almost 5.000 cross-border mergers and takeovers (Weitzel \& Berns, 2006). The frequently cited study by Wheeler and Modyho (1992) and from Hines (1995) showed little overall significant effect of corruption on incoming foreign direct investment (Zurawicki \& Habib, 2010).

Corruption in China is based on a series of professional and unprofessional sources ubiquitous, but the inflow of investment is very important to this country. The ratio of FDI to GDP is in international comparison very important. Another paradox was during the reign of President Suharto in Indonesia. Earned the pseudonym "Ten Percent", which meant well established and respected size of the bribe. Despite this fact, Indonesia has been a major recipient of FDI, mainly from Japan (Wei, 2000).

Sanyal and Samantha (2008) examined the flows of foreign direct investment from the US into 42 receiving countries for five years, taking into account the extent of corruption in these countries. US firms according to their findings, less invest in countries with high levels of corruption. However, the important role played the size of the foreign market, while the larger bigger markets are more attractive for investors. The level of corruption is losing importance if it is considered together with different economical and cultural factors.

Asediu (2006), for example, argues that the reduction of the level of corruption that exists in Nigeria to the level of South Africa, the level of positive impact on FDI corresponding $35 \%$ increase in the share of fuels and minerals in total exports. FDI is generally recognized as the accumulation of FDI for the time elapsed. This is a long-term decisions of multinational companies. FDI inflows, however, can be understood in terms of short-term 
decisions of multinational companies. Therefore, it is necessary to analyze the long-term and short-term decisions of multinational corporations in relation to corruption (Zhou,.2007).

\section{Methodology}

Quantitative research can be divided into two sections. First section is focused on determining the relationship between the level of corruption, and foreign direct investment inflows using correlation analysis. This should verify the existence of interdependence between these two variables of corruption measured by corruption perception index $(\mathrm{x})$ and foreign direct investment $(\mathrm{y})$. Tightness of this relationship is measured by correlation coefficient. Consequently, if the existence of this relationship is confirmed, it is possible to determine on the cross-sectional data from 88 , respectively 172 countries how big this relationship is. This is done using methods of regression analysis as introduced in the second section of this chapter.

\subsection{Correlation Analysis}

Correlation analysis is done to verify the hypothesis whether globally there is a statistically significant negative relationship between corruption and FDI inflows. This is done on the sample of countries. Specifically, these countries are analyzed: Afghanistan, Albania, Algeria, Angola, Argentina, Armenia, Australia, Austria, Azerbaijan, Bahamas, Bahrain, Bangladesh, Barbados, Belarus, Belgium, Benin, Bhutan, Bolivia, Bosnia and Herzegovina, Botswana, Brazil, Brunei, Bulgaria, Burkina Faso, Burundi, Cambodia, Cameroon, Canada, Cape Verde, Central African Republic, Colombia, Comoros, Congo Republic, Costa Rica, Côte d'Ivoire, Croatia, Cuba, Cyprus, Czech Republic, Democratic Republic of the Congo, Denmark, Djibouti, Dominica, Dominican Republic, Ecuador, Egypt, El Salvador, Equatorial Guinea, Eritrea, Estonia, Ethiopia, Finland, France, FYR Macedonia, Gabon, Gambia, Georgia, Germany, Ghana, Greece, Guatemala, Guinea, Guinea-Bissau, Guyana, Haiti, Honduras, Hong Kong, Hungary, Chad, Chile, China, Iceland, India, Indonesia, Iran, Iraq, Ireland, Israel, Italy, Jamaica, Japan, Jordan, Kazakhstan, Kenya, Kiribati, Korea (North) Korea (South), Kuwait, Kyrgyzstan, Laos, Latvia, Lebanon, Lesotho, Liberia, Libya, Lithuania, Luxembourg, Macau, Madagascar, Malawi, Malaysia, Maldives, Mali, Malta, Mauritania, Mauritius, Mexico, Moldova , Mongolia, Montenegro, Morocco, Mozambique, Myanmar, Namibia, Nepal, Netherlands, New Zealand, Nicaragua, Niger, Nigeria, Norway, Oman, Pakistan, Panama, Papua New Guinea, Paraguay, Peru, Philippines, Poland, Portugal, Qatar, Romania, Russia, Rwanda, Saint Lucia, Saint Vincent and the Grenadines, Samoa, Sao Tome \& Principe, Saudi Arabia, Senegal, Serbia, Seychelles, Sierra Leone, Singapore, Slovakia, Slovenia, Solomon Islands, Somalia, South Africa, South Korea, Spain, Sri Lanka, Sudan, Swaziland, Sweden, Switzerland, Syria, Taiwan, Tajikistan, Tanzania, Thailand, Timor-Leste, Togo, Tonga, Trinidad and Tobago, Tunisia, Turkey, Turkmenistan, Uganda, Ukraine, United Arab Emirates, United Kingdom, United States, Uruguay, Uzbekistan, Vanuatu, Venezuela, Vietnam, Yemen, Zambia, and Zimbabwe.

For this paper a standard Pearson product-moment correlation coefficient (also referred to as Pearson's r) which is a measure of the linear correlation (dependence) between two variables $\mathrm{X}$ and $\mathrm{Y}$ is used. Correlation coefficient $r$ can take a value between +1 and -1 , where 1 is total positive correlation, 0 is no correlation, and -1 is total negative correlation. First option is that the correlation coefficient is positive, i.e. $r>0$ ) and then y grows with growing $\mathrm{x}$.

Second option is that the correlation coefficient is negative $r<0$ ) which implies that $\mathrm{y}$ with growing $\mathrm{x}$ decreases. This means there is a negative linear correlation. Third option means that $|r|=1$, then this is so called functional relationship where all points are perfectly aligned. Finally, $r=0$ which means that that the two variables are totally independent. Generally speaking, the closer is $|r|$ to 1, the tighter is the relationship (FZP, 2012).

In order to conduct statistical evaluation, it is necessary to test independence of variables $x$ and $y$ using test of correlation coefficient. If $r$ is significantly different than 0 then between $x, y$ exists a linear relationship. This can be formalized into

$$
\begin{gathered}
H_{0}: r=0 \text { (no correlation) } \\
H_{1}: r \neq 0 \text { (there is a correlation) }
\end{gathered}
$$

If $H_{0}(r=0)$, is valid then the values of $r$ have normal distribution with all related statistics. This is important for calculation of critical values. The critical values are determined

For significance level $\alpha$ and $n$ number of observations and can be found in tables. This can be further compared with the calculated value. Basically, there are two possible outcomes. If $|r|>r_{k}$, then $H_{0}$ is rejected and then we can assume correlation between $x$ and $y$. If $|r| \leq r_{k}$, we cannot reject $H_{0}$ hypothesis and we assume independence 
between variables (FZP, 2012)

For analysis of relationship between corruption and FDI the following data are used. Firstly, statistics of UNCTAD are used as a source of data about FDI. In this research FDI per capita is used instead of total FDI as it better represents spread of FDI per population. For the corruption level, CPI index is used. Corruption is evaluated as an index with values inbetween 0 to 10 , where 10 means no corruption. For better interpretation an inverse value of index is used, where 10 is the highest level of corruption and 0 is the lowest level of corruption.

\subsection{Test of Correlation Coefficient Significance}

Test of correlation coefficient significance is done by comparison with table values using a $t$-test with $n-2$ degrees of freedom where $n$ is number of analyzed countries that year.

(VASSARSTATS, 2013)

This is depicted below in equation.

Test of correlation coefficient significance

\section{Results}

$$
\begin{gathered}
\mathrm{t}=\mathrm{r} \\
\sqrt{\left[\left(1-\mathrm{r}^{2}\right) /(\mathrm{N}-2)\right]}
\end{gathered}
$$

For the year 2000 is the result of the correlation coefficient for $n=88$ and $r=-056 t=-6.268$, ie. It is therefore the result statistically significant at a significance level of 0.05 .

2005 is the result of the correlation coefficient for $n=88$ and $r=-0.39 t=-3.928$, i.e. it is therefore the result statistically significant at a significance level of 0.05 .

For 2011, the result of the correlation coefficient for $n=88$ and $r=-0.467 t=-4.898$, i.e. it is therefore the result statistically significant at a significance level of 0.05 .

For the year 2011 for 172 countries for $\mathrm{n}=172$ and $\mathrm{r}=-0.379 \mathrm{t}=-5.34$, i.e. it is a statistically significant relationship at a significance level of 0.01 .

The results show that there is a significant relationship globally for each year across the analyzed countries sample. In order to determine not only how tight is the relationship but also how big this relationship is, a regression framework must be deployed.

In case of only two variables, a simple regression model may be appropriate where the dependent variable is defined the level of FDI and the independent variable is the level of corruption as represented by CPI. This model is described in equation $\mathrm{XY}$

$$
\text { Eq xy FDI }=a+b \text { CPI }+u
$$

Where $a$ is constant, $b$ is the slope coefficient that determined the level by which CPI influenced FDI and $\mathrm{u}$ is an error term. A standard least square method is used and the model is verified both statistically and economically.

\subsection{Significance of Regression Model}

For regression model specified above, coefficient of determination is calculated as well as the t-test for the $b$ coefficient.

Null hypothesis tested in the model is that $H_{0}: b=0$. If valid, statistics is t-distributed with $n-2$ degrees of freedom.

The model presented above is analyzed using data for the years 2000, 2005 and 2011. With that, the sample has 88 observations, i.e. 88 countries are presented in the data. Data were obtained from the same source as the data for correlation analysis. Results of model estimation for the year 2000 are shown below.

Model output

Table 1. Regression statistics

\begin{tabular}{lll}
\hline Multiple R & 0.559277 & \\
$\mathrm{R} 2$ & 0.312791 & Standard Error \\
\hline & Coefficient & 381.1045
\end{tabular}


The results suggest that the model has a relatively low coefficient of determination which implies that the model explains the relationship between the variables only by 31 percent. This is not surprising, because FDI is influenced by many other factors such as investment incentives introduced by governments, along with, for example, the cost of labor and skilled workforce and other variables. Results also show that the effect of CPI on FDI is significant at the level of 99 percent and coefficient has the expected sign, i.e. negative. If we raise the corruption by one unit, then FDI per capita is reduced by $\$ 414$. This corresponds well with works of Zurawicki and Habib (2008)

The same analysis was performed for 2005 and 2011, the results of which are shown in the tables below.

Model output

Table 2. Regression statistics

\begin{tabular}{lll}
\hline Multiple R & 0.39008 & \\
$\mathrm{R} \mathrm{2}$ & 0.152162 & \\
\hline & Coefficient & Standard Error \\
\hline Constant & 1875.532 & 388.6126 \\
CPI & -266.308 & 67.78582 \\
\hline
\end{tabular}

The results for 2005 indicate that the model explains the behavior of the two variables only by 15 percent. Again it should be noted that FDI is largely influenced by other variables that are not represented in the model and are not the subject of this research.

Corruption, as a factor, is however significant and we can interpret the results as follows. When corruption is increased by one unit, FDI per capita is reduced by $\$ 266$.

Analyzed as last is the year 2011. The results of the analysis are shown in the table below.

Model output

Table 3. Regression statistics

\begin{tabular}{lll}
\hline Multiple R & 0.467005 & \\
\hline R 2 & 0.218093 & \\
& Coefficient & Standard Error \\
Constant & 2895.378 & 473.2067 \\
CPI & -402.619 & 82.2056 \\
\hline
\end{tabular}

The coefficient of determination is higher than in the previous model, however, it is still low, i.e. approx. at the level of 0.22 . Estimation for CPI parameter suggests that increase in corruption by one unit leads to reduced FDI per capita of $\$ 402$.

Overall, the results from the three linear regression models can be summarized as follows. All models have a statistically significant relationship between FDI as the dependent variable and the CPI as an independent variable. This relationship is negative. At the same time, all three models have confirmed the need for the inclusion of other explanatory variables for us to fully understand the causes of movement in FDI. This research, however, confirms and provides rigorous proof for relationship between FDI and corruption. Also, it shows that this relationship changes over time and is subject to other factors.

\section{Conclusions}

By using correlation and regression analysis was analyzed the relationship between FDI and the level of corruption on a global scale. There is a statistically significant negative correlation between corruption and FDI inflows and it was verified in the context of correlation and regression analysis for 88 countries for the years 
2000, 2005 and 2011. The results of the regression analysis of three linear regression models have proved statistically significant relationship between FDI as the dependent variable and the CPI as an independent variable and a negative relationship. There was quantified impact of corruption on FDI in terms of changes in FDI per capita due to the increase of corruption for one point. At the same time, all three models have confirmed the need for the inclusion of other explanatory variables to fully understand the causes of movement of FDI. Results of regression analyzes for the years 2000, 2005 and 2011 confirm the negative relationship between the level of corruption and FDI also suggest the model must be extended further because of the low coefficient of determination. This is not surprising, because FDI is influenced by many other factors such as investment incentives, along with the cost of labor and level of workforce skills. All three models thus confirmed the need for the inclusion of other explanatory variables to be able to fully understand the causes of movement of FDI. This is beyond the scope of this work and therefore the researchers propose this as the next step for further investigation.

\section{References}

Al-Sadig, A. $(2009,29 / 5)$. The Effect of Corruption on FDI. Cato journal Retrieved from http://object.cato.org/sites/cato.org/files/serials/files/catojournal/2009/5/cj29n2-4.pdf

Buehn, A., \& Schneider, F. (2007-2009, 1). Shadow Economies and Corruption All Over the World: Revised Estimates for 120 Countries. Economics. The Open-Access, Open-Assessment E-Journal. Retrieved from http://www.economics-ejournal.org/economics/journalarticles/2007-9

FZP. Statistika. (2012). FZP UJEP.cz. Retrieved from http://fzp.ujep.cz/ synek/statistika/

Hobbs, N. (2005). Corruption in World Bank Financed Projects: Why Bribery is a Tolerated Anathema.

Kenny, C. (2006). Measuring and reducing the impact of corruption in infrastructure. World Bank Policy Research Working Paper 4099, Washington D. C: The World Bank: Retrieved from http://www-wds.worldbank.org/servlet/WDSContentServer/WDSP/IB/2006/12/14/000016406_2006121412 0802/Rendered/PDF/wps4099.pdf

Deutsche Gesellschaft für Technische Zusammenarbeit (GTZ) GmbH. (2008). Costs of Corruption: Everyone Pays - And the Poor More than Others. GIZ. Retrieved from http://www.giz.de/fachexpertise/downloads/gtz2008-en-german-uncac-project-costs-of-corruption.pdf

Lambsdorff, J. G. (2003, 4/3). How Corruption Affects Persistent Capital Flows. Economics of Governance, pp.229-244. Retrieved from http://www.icgg.org/literature/E_Gov.pdf

Bray, J. (2007). Facing Up to Corruption 2007: A practical business guide. London: Control Risks. Retrieved from http://www.giaccentre.org/documents/CONTROLRISKS.CORRUPTIONGUIDE.pdf

Pricewaterhouse Coopers. (2008). Konfrontace korupce: Obchodni př́pad pro efektivni anti-korupčni program.

Wei, S. J. (2000). How taxing is corruption on International investors? Review of Economics and Statistics, 82, 1-11. Retrieved from http://users.nber.org/ wei/data/wei2000a/wei2000a.pdf

Weitzel, U., \& Berns, S. (2006, 37/6). Přeshraniční převzetí, o korupci a aspektech vládnutí. Journal společnosti International Business Studies.

Zurawicki, L., \& Habib, M. (2010, 9/7). Corruption And Foreign Direct Investment: What Have We Learned? International Business \& Economics Research Journal.

Wei, S. J. (2000). How taxing is corruption on International investors? Review of Economics and Statistics, 82, 1-11. Retrieved from http://users.nber.org/ wei/data/wei2000a/wei2000a.pdf

Lambsdorff, J. G. (2004, May 31). Between Two Evils - Investors Prefer Grand Corruption! Diskussionsbeitrag.

Zhou, Y. (2007). An empirical study of the relationship between corruption and FDI: with sample selection error correction. Retrieved from http://www.etsg.org/ETSG2007/papers/zhou.pdf.

Sanyal, R., \& Samanta, S. (2008, 10). Effect of Perception of Corruption On Outward US Foreign Direct Investment, Global Business and Economics Review, 123-140.

Asiedu, E. (2006, 29). Foreign Direct Investment in Africa: The Role of Natural Resources, Market Size, Government Policy, Institutions and Political Instability, World Economy, 63-77.

Lambsdorff, J. G. (1999, November). Corruption in Empirical Research - A Review, Also published as a Transparency International Working Paper. 1999. Retrieved from http://gwdu05.gwdg.de / uwvw/downloads/contribution05_lambsdorff.pdf 
Mauro, P. (1995, 110/3). Corruption and Growth. Quarterly Journal of Economics, 681-712. Retrieved from http://elsa.berkeley.edu/ saez/course131/Mauro95.pdf

Rose-Ackerman, S. (1975, 83/1). The Economics of Corruption, Journal of Political Economy, 187-203.

Transparency International (2015). About us. Retrieved from http://www.transparency.cz/about-us/

Transparency International. (2011). Indexy. Retrieved from http://www.transparency.cz/indexy/

$\begin{array}{llll}\text { Transparency } & \text { International. } & \text { (2014). } & \text { Overview. }\end{array}$ http://www.transparency.org/research/cpi/overview

VASSARSTATS. (2001-20013). Significance of a Correlation Coefficient. Vassarstats.net Retrieved from http://vassarstats.net/rsig.html

\section{Copyrights}

Copyright for this article is retained by the author(s), with first publication rights granted to the journal.

This is an open-access article distributed under the terms and conditions of the Creative Commons Attribution license (http://creativecommons.org/licenses/by/3.0/). 